\title{
Effects of fertilizer and weed species richness on soil nematode community in a microcosm field experiment
}

\author{
Xinli Niu ${ }^{1, *}$, Yongfan Cheng ${ }^{1}$, Xiaopei Feng ${ }^{1}$, Feng Sun ${ }^{2}$, Yanfang $\mathrm{Gu}^{1}{ }^{1,}$ \\ 1 School of Life Science, Henan University, Kaifeng 475004, China \\ 2 School of Life Science, South China Normal University, Guangzhou 510631, China
}

H I G H L I G H T S

- Fertilizer increased soil nematode abundance and decreased the ecological index of soil nematode community.

- Except for bacterivore density, weed species richness had no effect on soil nematode abundance and increased the ecological index of soil nematode community.

- Fertilizer degraded, whereas weed species richness enhanced soil nematode community structure. Weed species richness may relieve the negative effect of fertilizer on the diversity of nematode community.

\section{ARTICLE INFO}

Article history:

Received April 28, 2021

Revised September 7, 2021

Accepted September 21, 2021

Keywords:

Fertilizer

Farmland weed

Weed species richness

Soil nematodes

Community structure

Soil food web
GRAPHICAL ABSTRACT

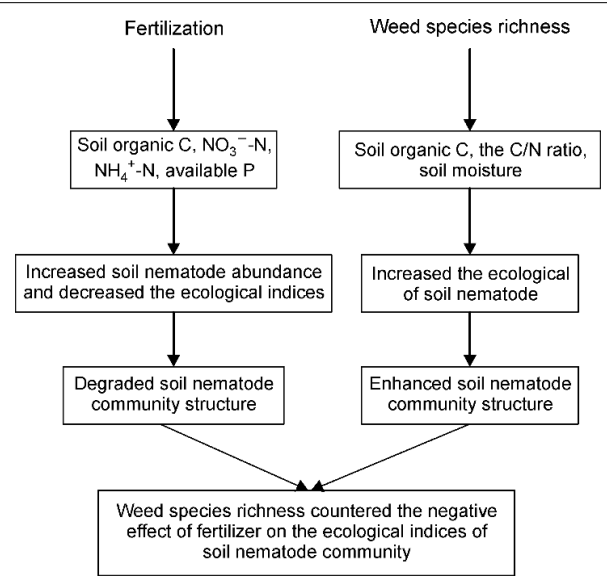

A B S T R A C T

Both fertilizer and plant species richness may affect the soil nematode community. However, the influence of fertilizer and weed species richness interaction is unclear. Nematode abundance and biodiversity in wheat and weed plots soil treated with nitrogen, phosphate and potassium fertilizer addition and weed species richness $(0,1,2$ and 4 weed levels) were investigated in a long-term microcosm experiment established in 2010 at Kaifeng, China. The results demonstrated that fertilizer treatment increased the abundance of total nematode, bacterivores, and plant parasites whereas it decreased the total genera number, the Shannon-Wiener diversity index $\left(\mathrm{H}^{\prime}\right)$, Margalef richness index $(\mathrm{SR})$, the total maturity index ( $(\mathrm{MI})$, and structure index $(\mathrm{SI})$, and degraded the structure of the nematode community. In contrast, weed species richness increased these ecological indices and enhanced the structure of the nematode community. Principal component analysis (PCA) indicated that the fertilizer's effect was more significant than weed species richness. Redundancy analysis (RDA) demonstrated that fertilizer affected soil nematode mainly through increasing soil available phosphorus by 4.71 times and ammonium nitrogen content by $74.03 \%$; weed species richness increased the diversity indices of soil nematode mainly through enhancing soil moisture by $2.07 \%$. Our results suggest weed species richness may relieve the negative effect of fertilizer on the diversity of soil nematode community.

\footnotetext{
* Corresponding authors

E-mail address: guyanfang@henu.edu.cn (Y. Gu); niuxinli@henu.edu.cn (X. Niu)
}

\section{Introduction}

Soil nematodes are the most abundant mesofauna and occupy important positions at most trophic levels in the soil food web (Yeates, 2003). Soil nematodes comprise a wide 
range of trophic groups, including bacteria, fungi, and plant feeders, as well as predators and omnivores (Yeates et al., 1993). Previous studies have reported that soil nematodes are sensitive to various disturbances (e.g., agricultural management) and can be used as ecological indicators (Todd, 1996; Neher, 2001; Zhao and Neher, 2013; Zhao et al., 2013).

From 1996 to 2005, Chinese cereal grain yields increased by $10 \%$, while use of chemical fertilizers increased the amount by $51 \%$ (Chen et al., 2011). Nitrogen, phosphorus, and potassium (NPK) are the most common elements in limiting primary productivity in most terrestrial ecosystems. Previous field studies focused on the effects of NPK fertilizer on soil nematode abundance and the diversity index of soil nematode community, and have revealed different results. Compared with the control treatment, addition of NPK fertilizer had no effects on the abundance of nematode trophic groups (Todd, 1996; Forge, et al., 2005; Zhu and Zhu, 2015; Hu et al., 2018). Studies also found NPK fertilizer significantly increased total nematode density (Okada and Harada, 2007; Hu et al., 2018), and bacterivorous nematode density in agricultural ecosystems (Pan et al., 2010; Hu and Qi, 2010; Sun, et al., 2016), relative to no-fertilizer treatments. However, addition of NPK fertilizer significantly decreased the abundance of total nematode (Zhang et al., 2009; Zhang et al., 2014), fungivores (Zhang et al., 2016), and plant parasites (Zhang et al., 2009; Pan et al., 2010) compared to the control soils. In addition to its impacts on nematode abundance, NPK addition has different results on soil nematode diversity indices. Relative to the control, NPK fertilizer decreased the nematode maturity index (Forge et al., 2005) and had no impact on the nematode diversity (Zhang et al., 2009). These results indicated that the effect of fertilizer on soil nematode community depends on the specific environment. A recent study indicated that fertilization patterns (control, inorganic fertilizers, and mixed fertilizers) had a greater influence on the nematode gut microbiome than fertilization duration (Zheng et al., 2020).

Also, soil nematode aboundance and community diversity may be influenced indirectly by shifts in plant species diversity and plant identity (De Deyn et al., 2004). Studies that focused on the effects of plant species richness on soil nematode communities are abundant. Many studies have reported positive or neutral effects of plant species richness on the soil nematode community structure (Lu et al., 2016; Dietrich et al., 2021). Nematode genera number tended to be positively related to plant species richness (Viketoft et al., 2009). Plant species diversity may increase soil nematode density by changing soil physical and chemical characters (Scherber et al., 2010; Eisenhauer, et al., 2013). Study also demonstrated that plant species diversity increased the Simpson evenness diversity index of the soil nematode community (Deyn et al., 2004). However, other work presented evidence that demonstrated that plant species diversity did not affect nematode abundance (De Deyn et al., 2004) and had no effect on nematode diversity (Sohlenius et al., 2011). Farmland weeds are always considered harmful plants and to be among the biggest threat to agriculture (Blackshaw et al., 2004; Ross and
Van Acker, 2009). However, weeds are an essential component of agroecosystems (Marshall et al., 2003), and play a vital role in supporting biological diversity (Marshall et al., 2003; Gibbons et al., 2006); they affect both the microbefeeding nematode and the herbivorous nematode (Loreau et al., 2001; Wardle, et al., 2004). Weeds serve as reservoirs for nematodes (Anwar et al., 2009). In a typical winter wheat field, there are more than 30 kinds of weeds, mainly consisting of Gramineae, and broadleaf weeds. Gramineae weed Avena fatual, broadleaf weeds Medicago sativa, Cichorium intybus, and Descurainia sophia are the most frequent agricultural weeds which geminate, grow and occur with winter wheat as accompanying species at the same time. Previous studies focused on the effect of weeds on plant parasite nematodes (Anwar et al., 2009; Thomas et al., 2009). The effect of the combination of winter wheat and different weed species richness on soil nematode community in farmland ecosystems is still unknown.

Studies have demonstrated that fertilizer, especially NPK fertilization treatment, promotes crops' growth, and affects weed species richness (Wan et al., 2012). NPK fertilizer management help to maintain soil weed seed bank diversity (Feng et al., 2008) and weed species richness (Jiang et al., 2018). Competition for nutrient and solar radiation between crops and weeds was found to be the main indirect effect of fertilization on weed species diversity changes (Tang et al., 2014). If the interaction of NPK fertilizer and weed species richness affect soil nematode community is still not known. A review study has demonstrated that plant species richness had no or weak effects on the abundance and the ecological indices of soil nematode community in a short time duration (Anderson, 2011). The effect of plant species richness on the soil nematode community depended on experimental duration (Eisenhauer et al., 2012). Soil nematodes contribute to nutrient cycling and have important roles in the soil food web as consumers at various levels (Lu et al., 2020). Compared to weed species richness, NPK fertilizer may have more effects on abundance and community structure of soil nematodes, which are ascribed to the high nutrient content in the soil resulting from use of fertilizer.

The Huang-Huai-Hai plain has become the main grain production area in China. To increase grain yield, chemical fertilizer is used extensively, which has caused a series of issues including production costs and environmental problems such as eutrophication of groundwater and soil acidification (Zhao et al., 2006). In addition, the extensive use of herbicides significantly decreased weed species diversity in cropland (Schmitz et al., 2014). Soil nematode responses to weed species richness combined with NPK fertilizer are poorly understood in the Huang-Huai-Hai plain. In this study, we designed a plastic box experiment to explore the impacts of NPK fertilization, weed species richness, and the interaction of NPK fertilizer and weed species richness on the soil nematode community in the winter wheat field. We hypothesize that: 1) NPK fertilizer may decrease but weed species richness may increase the abundance and diversity of 
soil nematode; 2) the interaction of NPK fertilizer and weed species richness may affect the soil nematode community; 3 ) the effect of NPK fertilizer on soil nematode community may be more remarkable than that of weed species richness.

\section{Materials and methods}

\subsection{Site description}

This study was conducted at the crop field station of Henan University $\left(34^{\circ} 48^{\prime} \mathrm{N}, 114^{\circ} 18^{\prime} \mathrm{E}\right)$, Kaifeng City, China. The temperate monsoon climate has four distinct seasons, with an average annual precipitation of $634.20 \mathrm{~mm}$, a mean annual temperature of $14^{\circ} \mathrm{C}$, and an average annual solar illumination of $2267.60 \mathrm{~h}$. The soil originates from the Yellow River's alluvial sediments and is classified as fluvisol (IUSS Working Group W.R.B.2007). Prior to use of fertilizer, the soil contained approximately $0.30 \mathrm{~g} \mathrm{~kg}^{-1}$ total nitrogen, 0.02 $\mathrm{g} \mathrm{kg}^{-1}$ ammonium nitrogen, $0.61 \mathrm{~g} \mathrm{~kg}^{-1}$ total phosphate, 0.01 $\mathrm{g} \mathrm{kg}^{-1}$ available phosphate and $3.2 \mathrm{~g} \mathrm{~kg}^{-1}$ organic carbon and had a $\mathrm{pH}$ of 7.41 .

\subsection{Weed seedlings}

The weed species were legume (Medicago sativa), Compositae (Cichorium intybus L.), forb (Avena fatua), and Cruciferae (Descurainia sophia). On September 10th each year, from 2010 to 2013 , seeds of weeds were sown on wet paper in Petri dishes and placed in a climate chamber (14 h light, $60 \%$ moisture, $20^{\circ} \mathrm{C}$ ). Then germinated seeds of each species were transplanted to seedling trays filled with soil (2:1, compost:soil) 14 days after sowing.

\subsection{Experimental design and treatments}

The experimental design is shown in Table 1. A fertilizer addition and weed species richness experiment was arranged in blocks as a complete randomized design and established in October 2010. Treatments consisted of two factors, including fertilizer (control; nitrogen, phosphorus, and potassium fertilizer) and weed species richness $(0,1,2$, and 4$)$ (Table 1). There were 72 plots including 36 control treatments and 36 NPK fertilizer treatments. These were both composed of 6 plots with 0 weed species richness, 12 plots with 1 weed species richness, 12 plots with 2 weed species richness, and 6 plots with 4 weed species richness. We had 4 weed species in our experiment. Under the 1 , and 2 weed species richness treatments, we adopted fake replicates, and every 2 plots were chosen as 1 replicate to avoid the differences in results from weed species selection. Each of the 72 experimental plots consisted of 72 plastic boxes of $75 \mathrm{~cm} \times 50 \mathrm{~cm} \times 50 \mathrm{~cm}$ arranged randomly in 6 rows and 12 columns in the experiment field and surrounded by a 1-m wide buffer strip. 72 experimental plots were redistributed randomly every two weeks in order to eliminate a possible source of experimental error. There were two holes $(3 \mathrm{~cm} \times 3 \mathrm{~cm})$ in the bottom of the boxes. Fluvisol soil from the alluvial sediments of the Yellow River mentioned above was mixed well, and $50 \mathrm{~kg}$ of soil was placed in each plastic box, and the depth of soil in each plastic box was $45 \mathrm{~cm}$, and made the same rotation a winter wheat (Triticum aestivum) and 4 species weeds - maize (Zea mays).

Weeds and wheat were sown in October and harvested in early June the following year. The planting distribution of weeds and wheat is shown in Fig. 1. Eight wheat plants were uniformly planted in each box's center, and either $0,1,2$, or 4 species of weed plants (each with approximately five leaves) from the seedling trays were planted around the eight wheat plants. Maize was sown in June and harvested in September. Four individuals of maize were planted in per plot. Urea was used as $\mathrm{N}$ fertilizer, calcium superphosphate and potassium sulfate were used as $\mathrm{P}$, and $\mathrm{K}$ sources, respectively, and both were mixed uniformly with soils.

For the winter wheat and weed plots, $\mathrm{N}$ application consisted of basal fertilization (urea $90 \mathrm{~kg} \mathrm{ha}^{-1}$ ) and topdressing (urea $60 \mathrm{~kg} \mathrm{ha}^{-1}$ ), whereas $\mathrm{P}$ and $\mathrm{K}$ applied as basal fertilizer (calcium superphosphate $75 \mathrm{~kg} \mathrm{ha}^{-1}$, potassium sulfate $150 \mathrm{~kg} \mathrm{ha}^{-1}$ ). Application time of basal fertilization and topdressing was October and March of the following year, respectively. For maize plots, basal fertilization (urea $60 \mathrm{~kg} \mathrm{ha}^{-1}$ ) and topdressing (urea $90 \mathrm{~kg} \mathrm{ha}^{-1}$ ) were used for the application of $\mathrm{N}$, and basal fertilization (calcium superphosphate $60 \mathrm{~kg} \mathrm{ha}^{-1}$, potassium sulfate $150 \mathrm{~kg} \mathrm{ha}^{-1}$ ) was used for the application of $\mathrm{P}$ and $\mathrm{K}$, respectively. The application time of basal fertilization and topdressing was June and August, respectively. Fertilizer level references were according to the local household fertilizer management.

\subsection{Nematodes sampling}

At the ripening stages of winter wheat on May 20th, 2013, and 2014 , the plants, including winter wheat and 1, 2, 4 species of weed in each box, were harvested. Plants (biomass) were cut at ground level and dried in an oven at $70^{\circ} \mathrm{C}$ to a constant weight. Five cores were collected randomly inside each box with a soil auger $(2 \mathrm{~cm}$ in diameter and $10 \mathrm{~cm}$ in depth) and combined carefully to obtain a total of 72 composite samples. Each composite soil sample was divided into two aliquots. The first was used to analyze soil physicochemical properties, including soil organic carbon (soil organic $\mathrm{C}$ ), total nitrogen (total $\mathrm{N}$ ), available phosphorus (available $\mathrm{P}$ ), nitrate nitrogen $\left(\mathrm{NO}_{3}{ }^{-} \mathrm{N}\right.$ ), ammonium nitrogen $\left(\mathrm{NH}_{4}{ }^{+}-\mathrm{N}\right.$ ), soil $\mathrm{C} / \mathrm{N}$ ratio (soil organic $\mathrm{C}$ /total $\mathrm{N}$ ), soil moisture, and soil $\mathrm{pH}$. The other was used to extract and identify soil nematodes.

Nematodes were extracted from $50 \mathrm{~g}$ of fresh soil from each composite sample following the modified Baermann funnel method (Barker, 1985). Another $50 \mathrm{~g}$ of fresh soil was analyzed for soil moisture content. Soil water content was measured gravimetrically using a soil sample from each box dried at $105^{\circ} \mathrm{C}$ for $24 \mathrm{~h}$. Extracted nematodes were preserved by TAF fixation $(40 \%$ formaldehyde $7 \mathrm{~mL}$, triethanolamine $2 \mathrm{~mL}$, and distilled water $91 \mathrm{~mL}$ ) in a refrigerator. According to 


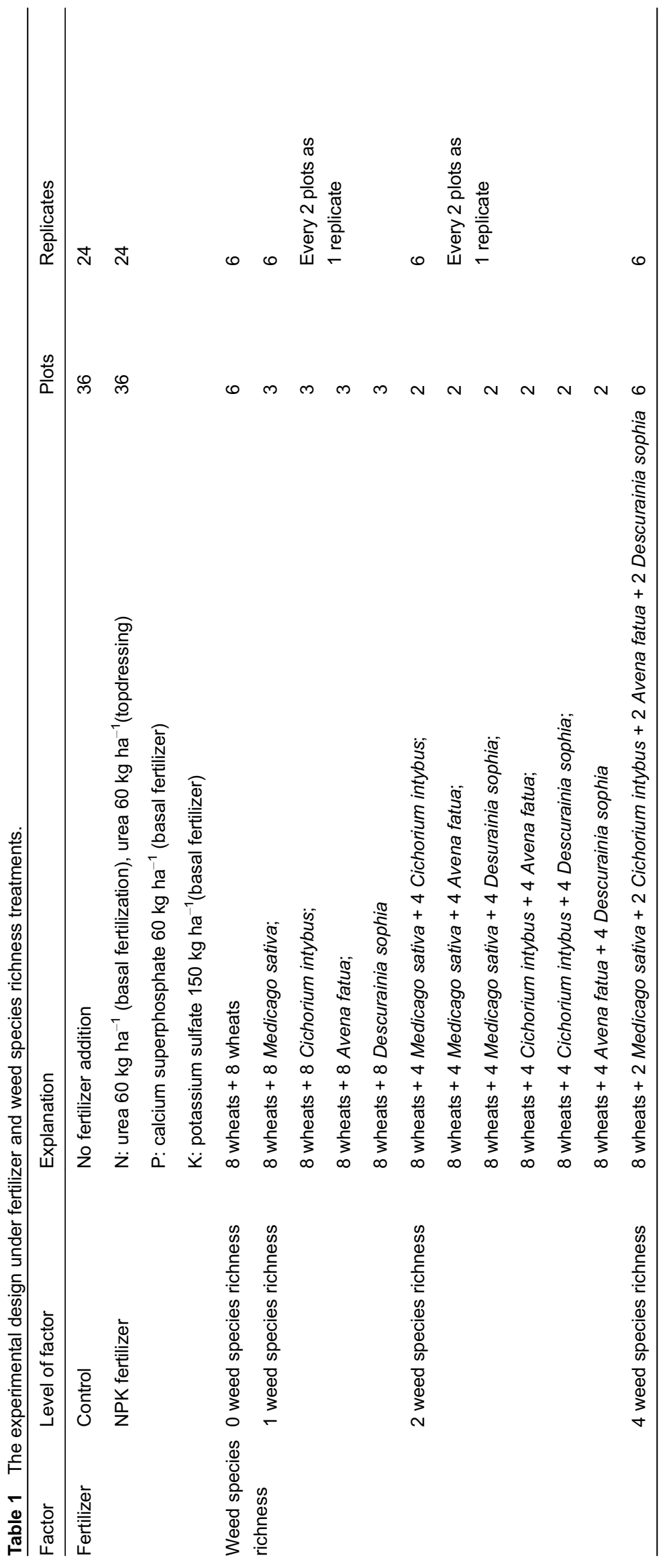




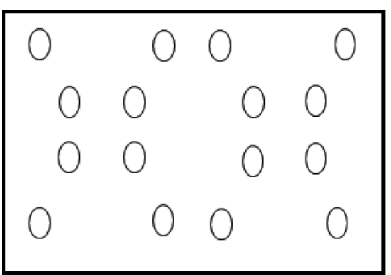

0 weed species richness

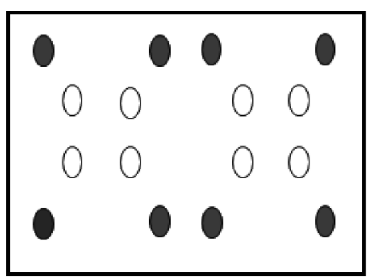

1 weed species richness

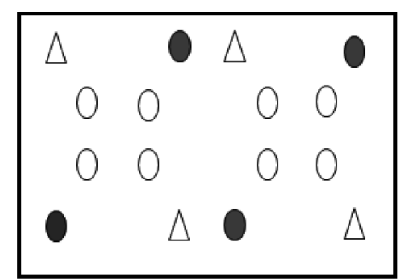

2 weed species richness

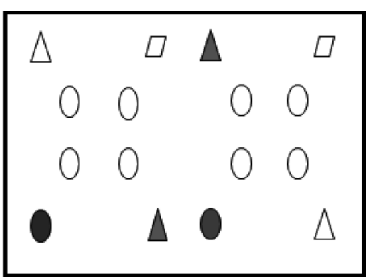

4 weed species richness

Fig. 1 Layout graph of wheats and weed plants in the experimental microcosm. $\circ$ indicates winter wheat; $\bullet$ indicates 1 weed species; $\bullet \Delta$ indicates 2 weed species; $\Delta \bullet \boldsymbol{\Delta}$ 口 indicates 4 weed species richness.

soil moisture content, $50 \mathrm{~g}$ fresh soil was converted into the weight dry soil, and nematode abundance was determined as the number of individuals per $100 \mathrm{~g}$ dry soil. Subsequently, 100 nematodes from each sample were identified by genus using an optical microscope (Motic, BA210, Motic Corporation). For samples with fewer than 100 nematodes, all specimens were identified. Soil nematodes were assigned to four trophic groups: plant parasites $(\mathrm{Pp})$, bacterivores $(\mathrm{Ba})$, fungivores $(\mathrm{Fu})$ and predators-omnivores $(\mathrm{Po})$ (Yeates et al., 1993) with corresponding colonizer-persister (cp) groups (Bongers, 1999). Nematodes in $\mathrm{cp}-1$ have short generation duration, high fecundity, and are regarded as enrichment opportunists and tolerant to disturbance and can be described as r-strategists. In contrast, cp-5 nematodes produce few large eggs, have a long-life cycle combined with a long generation time, and are generally intolerant of disturbance and inhabit stable, mature ecosystems (Ferris et al., 2001; Sieriebriennikov et al., 2014).

\subsection{Soil nematode community analysis}

The nematode communities were characterized by the Shannon-Wiener diversity index $\left(\mathrm{H}^{\prime}\right)$, Margalef richness index (SR), the Pielou evenness index $(E)$, the total maturity index $\left(\sum \mathrm{MI}\right)$, the plant-parasitic maturity index $(\mathrm{PPI})$, enrichment index (EI), structure index (SI), and channel index $(\mathrm{Cl})$. $\Sigma \mathrm{Ml}, \mathrm{PPI}, \mathrm{El}, \mathrm{SI}$, and $\mathrm{Cl}$ are calculated by assigning a colonizer-persister ( $c p$ ) weight to nematode genera.

The $\Sigma \mathrm{Ml}$ and $\mathrm{PPI}$ values were computed for each sample, as described by Bongers (1990). Small and large $\sum \mathrm{Ml}$ and PPI values represent disturbed and stable soil ecosystems, respectively. Also, $\mathrm{El}, \mathrm{SI}$, and $\mathrm{Cl}$ values were computed for each sample (Ferris et al., 2001). El and SI were used to characterize the soil food webs. A high El value indicates an enriched environment, and a high $\mathrm{SI}$ value indicates a complex and stable food web. $\mathrm{Cl}$ was calculated for each sample to evaluate soil food web decomposition pathways (Ferris and Matute, 2003).

\subsection{Soil physicochemical properties and plant determination}

Soil organic $\mathrm{C}$ was determined by the potassium dichromate external heating method. Soil total $\mathrm{N}$ was determined by the
Kjeldahl digestion method. Soil available $\mathrm{P}$ was determined by molybdenum antimony colorimetry, $\mathrm{NaOH}$ melting, and 0.5 mol L-1 $\mathrm{NaHCO}_{3}$ extraction. The concentrations of $\mathrm{NO}_{3}{ }^{-} \mathrm{N}$ and $\mathrm{NH}_{4}{ }^{+}-\mathrm{N}$ were measured using a Smart Chem 200 Discrete Auto Analyzer (AMS Systea Italy). Soil pH was measured in a $1: 2.5 \mathrm{soil} / \mathrm{CaCl}_{2}\left(0.01 \mathrm{~mol} \mathrm{~L}^{-1}\right)$ suspension (Bao, 2000).

\subsection{Data analysis}

The average data of every 2 plots under the 1 , and 2 weed species richness treatments was as 1 replicate data, and variance analysis used the average data. Data were used to determine natural log, square root, or they were rank, transformed when required to achieve normality and homogeneity of variance. Three-way ANOVA was performed to evaluate the effect of the fertilizer, weed species richness, and sample treatment time on the total nematode genera number, the abundance of total nematode and each trophic group, and the ecological indices of soil nematode community including $\mathrm{H}^{\prime}, \mathrm{SR}, \mathrm{E}, \Sigma \mathrm{Ml}, \mathrm{PPI}, \mathrm{El}, \mathrm{SI}$, and $\mathrm{Cl}$. If the effects were significant, the least significant difference (LSD) was used to test the effects of the fertilizer, weed species richness, and sample treatment time on soil nematodes' abundance and ecological indices. ANOVAs were performed with SPSS version 19.0 statistical software package (SPSS Inc, Chicago, IL, USA). The purpose of PCA in CANOCO version 4.5 (Ithaca NY, USA) was to examine the effects of NPK fertilizer and weed species richness on the composition of the soil nematode community. Redundancy analysis (RDA) was used to determine the relationship between soil physicalchemical properties, plant biomass including wheat and weed, and soil nematode community composition using CANOCO 4.5 software (Ithaca NY, USA). Monte Carlo permutation tests were applied to compute statistical significance $(n=499)$ (Lepš, 2003). Figures were plotted with GraphPad Prism 5.

\section{Results}

\subsection{Biomass of wheat and weeds}

The biomasses of wheat and four weed species are shown in Table 2. Compared with the control plots, fertilizer significantly 


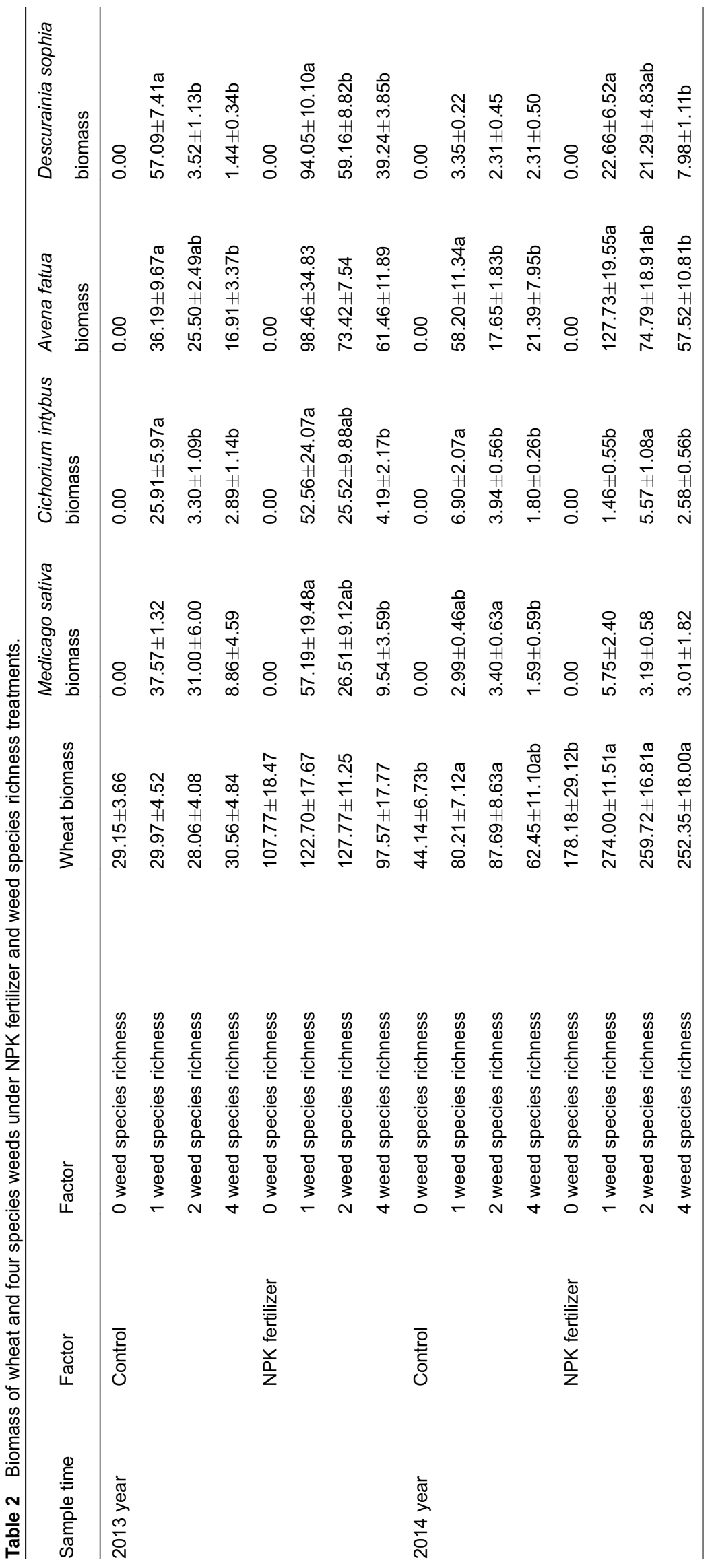


increased wheat biomass by 2.55 times $(F=147.45$, $P<0.001)$, weed Avena fatua biomass 1.96 times $(F=$ 41.93, $P<0.001)$, and Descurainia Sophia biomass 3.68 times $(F=25.58, P<0.001)$ (Table 2). Fertilizer did not affect the biomasses of weed Medicago sativa, and Cichorium intybus. Weed species richness significantly impacted primary production and wheat biomass (Table 3 ). Fertilizer and weed species richness both significantly affected primary production. Compared with the 0 weed species richness treatments, wheat biomass was increased $45.81 \%(F=2.75$, $P=0.102), 45.51 \%(F=2.94, P=0.091)$, and $64.40 \%(F=$ $5.57, P=0.023$ ) under the 1,2 , and 4 weed species richness treatments, respectively (Table 2 , Table 3 ). Primary production, and wheat biomasses in 2014 year were increased by 0.32 times, and 1.23 times than in 2013 year, respectively. The interaction of fertilizer and weed species richness significantly affected primary production. The interaction of fertilizer and sample time significantly affected primary production and wheat biomasses (Table 3).

\subsection{Soil physical and chemical properties}

Compared with the control plots, fertilizer increased organic $C$ by $4.63 \%(F=6.67, P=0.011)$, total $\mathrm{N} 13.73 \%(F=43.08$, $P<0.000), \mathrm{NO}_{3}{ }^{-} \mathrm{N} 2.02$ times $(F=334.91, P<0.000), \mathrm{NH}_{4}{ }^{+}-\mathrm{N}$ $74.03 \%(F=1076.31, P<0.000)$, and available $P 4.71$ times $(F=1567.34, P<0.000)$, but decreased $\mathrm{pH}$ by $0.28 \%(F=$ 3.50, $P=0.06$ ) (Table 3, Table 4). Relative to the 0 weed species richness, soil organic $C$ were increased by $3.03 \%(F=$ 5.52, $P=0.022), 7.28 \%(F=26.52, P<0.0001)$ and $63.54 \%(F$ $=63.54, P<0.0001)$ under the 1,2 , and 4 weed species richness treatments, respectively. Meanwhile, soil moisture was enhanced by $3.91 \%(F=4.00, P=0.049)$, and $7.45 \%(F=$ 10.16, $P=0.003$ ) under the 2 and 4 weed species richness treatments, respectively (Table 4 ). Soil organic $C$, and soil moisture were found the highest values under the 4 weed species richness (Table 4). The sample time significantly affected soil organic $\mathrm{C}$, the $\mathrm{C} / \mathrm{N}$ ratio, $\mathrm{NO}_{3}{ }^{-} \mathrm{N}$, available $\mathrm{P}$, and $\mathrm{pH}$. The interaction of factors significantly affected soil's physical and chemical properties (Table 3).

\subsection{Nematode abundance}

The total genera number was increased by $1.40 \%(P>0.1)$, 5.39\% $(F=3.22, P<0.1), 8.25 \%(F=11.39, P<0.01)$ under the 1, 2 and 4 weed species richness plots, respectively, in comparison with 0 weed species richness plots (Table 5 and Fig. 2A). The abundance of total nematodes, bacterivorous, and plant parasites were increased by $59.74 \%(F=44.95$, $P<0.001), 59.03 \%(F=71.57, P<0.001)$, and $50.38 \%(F=$ 21.56, $P<0.001)$ under the fertilizer plots, respectively, compared with the control plots (Table 5, Fig. 2B, 2C, and $2 \mathrm{E})$. Weed species richness significantly affected the abundance of bacterivores. The total genera number was higher $(F$ $=25.06, P<0.001)$ in 2013 than in 2014. The interaction of fertilizer and sample time significantly affected the abundance of bacterivores. The total genera number was affected significantly by the interaction of weed species richness and sample time (Table 5).

\subsection{Nematode composition}

A total of 32 and 30 soil nematode genera were identified during the study in 2013 (Supplementary Table 1) and 2014 (Supplementary Table 2), respectively. Bacterivores Rhabtidis and Cephalobus, plant parasites Pratylenchus were dominant genus (all proportions $>10 \%$ ). Tylenchorhynchus was the dominant genus in the fertilizer treatments. The abundance of bacterivores $(38.33 \%-53.08 \%)$ and plant parasites $(30.25 \%-$ $43.83 \%$ ) was highest, followed by omnivore-predators $(5.17 \%$ $-14.33 \%)$; fungivores $(3.33 \%-9.25 \%)$ had the lowest abundance in the control and NPK fertilizer treatments (Fig. 3).

\subsection{The ecological indices}

$\mathrm{H}^{\prime}, \mathrm{SR}, \mathrm{E}, \sum \mathrm{MI}, \mathrm{SI}$, and $\mathrm{Cl}$ were significantly decreased by $4.29 \%(F=11.03, P=0.001), 7.82 \%(F=15.66, P=$ $0.0001), 3.69 \%(F=14.94, P=0.0002), 5.23 \%(F=10.76, P=$ $0.0013), 16.11 \%(F=34.40, P<0.0001)$ and $60.46 \%(F=$ 23.58, $P<0.0001$ ) (Table 5, Fig. 4A, 4B, 4C, 4D, 4G and 4H) whereas El was increased by $18.97 \%(F=49.16, P<0.0001)$ (Table 5, Fig. 4F) when the fertilizer was added, relative to the control treatments. Weed species richness affected the indices $\sum \mathrm{Ml}$ and $\mathrm{SI}$ (Fig. 4D, 4G). $\sum \mathrm{Ml}$ was decreased by $5.09 \%(F=3.35, P=0.072)$ under the 1 weed species richness, compared with the 0 weed species richness (Fig. 4D). SI was decreased by $14.81 \%(F=11.66, P=0.0011)$, $7.57 \%(F=4.78, P=0.032)$, and $1.62 \%(F=0.11, P=0.743)$ under the 1,2, and 4 weed species richness, respectively, compared with the 0 weed species richness (Fig. 4G). $\mathrm{H}^{\prime}$ and $\mathrm{SR}$ increased with the increasing weed species richness were enhanced by $4.28 \%(F=4.29, P=0.044), 7.53 \%(F=5.15, P$ $=0.028)$ under 4 species richness plots, respectively, compared with the 0 weed species richness plots (Table 5 , Fig. 4A and 4B). Compared with in 2013, H', SR, and $E$ index was decreased by $7.22 \%(F=37.81, P<0.000), 10.19 \%(F=$ $29.74, P<0.000)$, and $3.69 \%(F=14.94, P<0.000)$ respectively, whereas $\sum \mathrm{Ml}$ index were increased by $4.19 \%(F=3.80$, $P=0.053$ ) in 2014, respectively. The interaction of fertilizer and weed species richness clearly affected E and El. The interaction of fertilizer and sample time substantially affected $\mathrm{SR}$ and $\Sigma \mathrm{Ml}$. $\mathrm{El}$ and $\mathrm{Cl}$ were affected by weed species richness and sample time interaction. The interaction of three factors affected $\mathrm{El}$ and $\mathrm{Cl}$ (Table 5, Fig. 4F and 4H).

3.6 Relationships between soil nematode community and fertilizer, weed species richness, sample time, plant biomass, or soil properties

Soil organic $\mathrm{C}$ was positively correlated with the nematode 


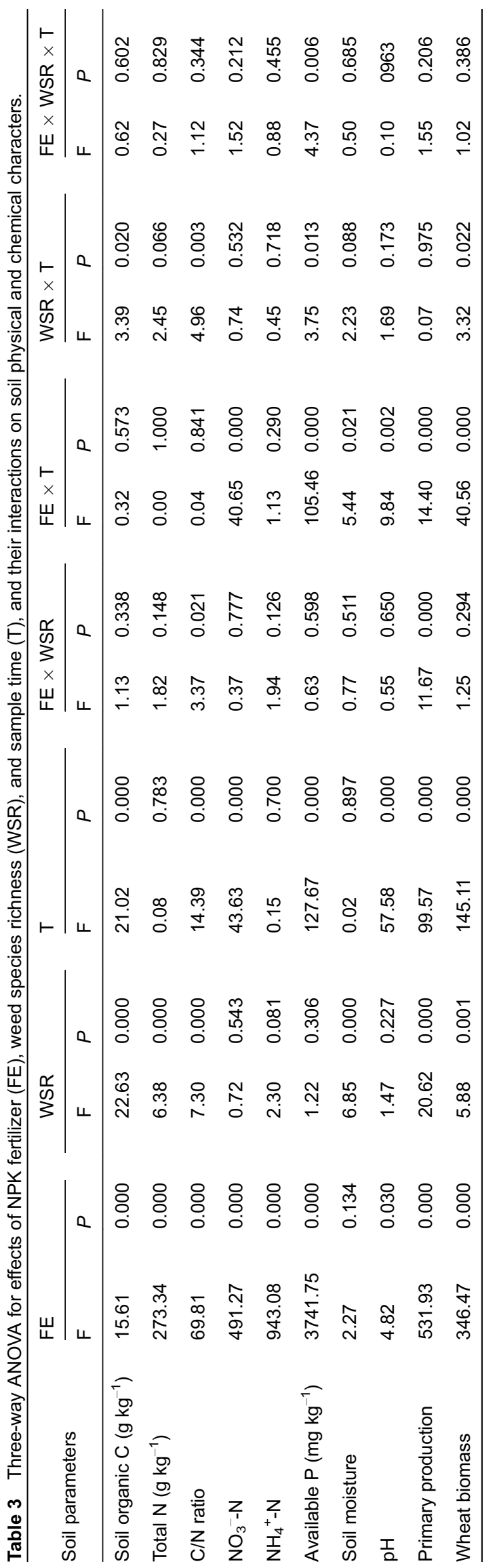






Fig. 2 The total genus richness of soil nematode (Fig. 2A); total soil nematodes (Fig. 2B), bacterivores (Fig. 2C), fungivores (Fig. 2D), plant parasites (Fig. 2E) and omnivore-predator individuals (Fig. 2F) per $100 \mathrm{~g}$ dry soil weight under the NPK fertilizer and weed species richness treatments in 2013 and 2014. All valued are means $\pm S E(n=6) .0,1,2$, and 4 represents $0,1,2$, and 4 weed species richness, respectively. ${ }^{* * *}$ indicates the significant difference between the control and NPK fertilizer treatments. Lowercase, and capital letters represent the significant differences under the different weed species richness in the control and NPK fertilizer treatments, respectively.

total genera number and nematode density except for plant parasites and $\mathrm{H}^{\prime}, \mathrm{SR}, \mathrm{E}$ (Table 6). Evident negative correlations were observed between $\mathrm{E}, \Sigma \mathrm{MI}$, and soil total $\mathrm{N}$ (Table 6). The soil $\mathrm{C} / \mathrm{N}$ ratio was correlated positively with the nematode total genera number, total nematode density, plant parasites density, omnivore-predator density, and $\mathrm{H}^{\prime}, \mathrm{E}, \Sigma \mathrm{Ml}$. $\mathrm{NO}_{3}{ }^{-}-\mathrm{N}$ was positively correlated with total nematode density, bacterivore density, plant parasites density, and $\mathrm{El}$ and negatively correlated with $\mathrm{E}, \sum \mathrm{MI}, \mathrm{SI}$, and $\mathrm{Cl}$. $\mathrm{NH}_{4}{ }^{+}-\mathrm{N}$ was negatively correlated with total nematode density, bacterivore density, plant parasites density, and $\mathrm{El}$ and positively correlated with $\mathrm{H}^{\prime}$, SR, E, $\Sigma \mathrm{MI}$, SI, and $\mathrm{Cl}$. Soil available $\mathrm{P}$ content was positively correlated with total nematode density, bacterivore density, plant parasites density, and $\mathrm{El}$ and negatively correlated with $\mathrm{H}^{\prime}, \mathrm{SR}, \mathrm{E}, \Sigma \mathrm{MI}, \mathrm{SI}$, and $\mathrm{Cl}$. Soil moisture was positively correlated with the nematode total genera number, omnivore-predator density, $\mathrm{H}^{\prime}, \mathrm{SR}, \mathrm{E}, \Sigma \mathrm{MI}$, and SI. Soil pH negatively correlated with bacterivores density and positively correlated with $\sum \mathrm{MI}$ (Table 6).

PCA indicated that fertilizer not weed species richness affected the composition of soil nematode community, because the distance between control and fertilizer quadrats was farther than that between weed species richness treatments (Fig. 5). The first and second axes explained $15.70 \%$, and $10.00 \%$ of the variance, respectively. The third and fourth axes explained altogether the $14.00 \%$ of the variance (Fig. 5). Redundancy analysis (RDA) showed that up to $54.55 \%$ of the total variance in soil nematode community composition was explained by the content of available $\mathrm{P}(F=$ 15.18, $P=0.002)$ and $\mathrm{NH}_{4}{ }^{+}-\mathrm{N}(F=15.01, P=0.002)$. The first $(F=15.71, P=0.002)$ and second axes $(F=2.49, P=0.002)$ of RDA analysis explained $10.80 \%$ and $2.80 \%$ variance, respectively (Fig. 6). Soil $\mathrm{C} / \mathrm{N}$ ratio $(F=6.19, P=0.002)$, Soil organic $C(F=1.83, P=0.014)$, soil moisture $(F=2.84, P=$ $0.004)$, and total $\mathrm{N}(F=10.25, P=0.002)$ significantly affected soil nematode community composition and together explained $22.22 \%$ of the variance. Weed biomass explained $11.82 \%$ of the variance. Mainly weed Avena fatua $(F=2.595, P=0.002)$ and weed Descurainia sophia $(F=1.783, P=0.030)$ significantly affected nematode community composition and explained $3.76 \%, 3.78 \%$ of the variance, respectively (Fig. 6).

\section{Discussion}

\subsection{Effect of NPK fertilizer on the soil nematode community}

Our experiment on the farmland conditions indicated that addition of NPK fertilizer clearly affects the nematode community abundance. In the present study, NPK fertilizer remarkably increased the abundance of total nematode, bacterivores, and plant parasites. The increasing effect of 


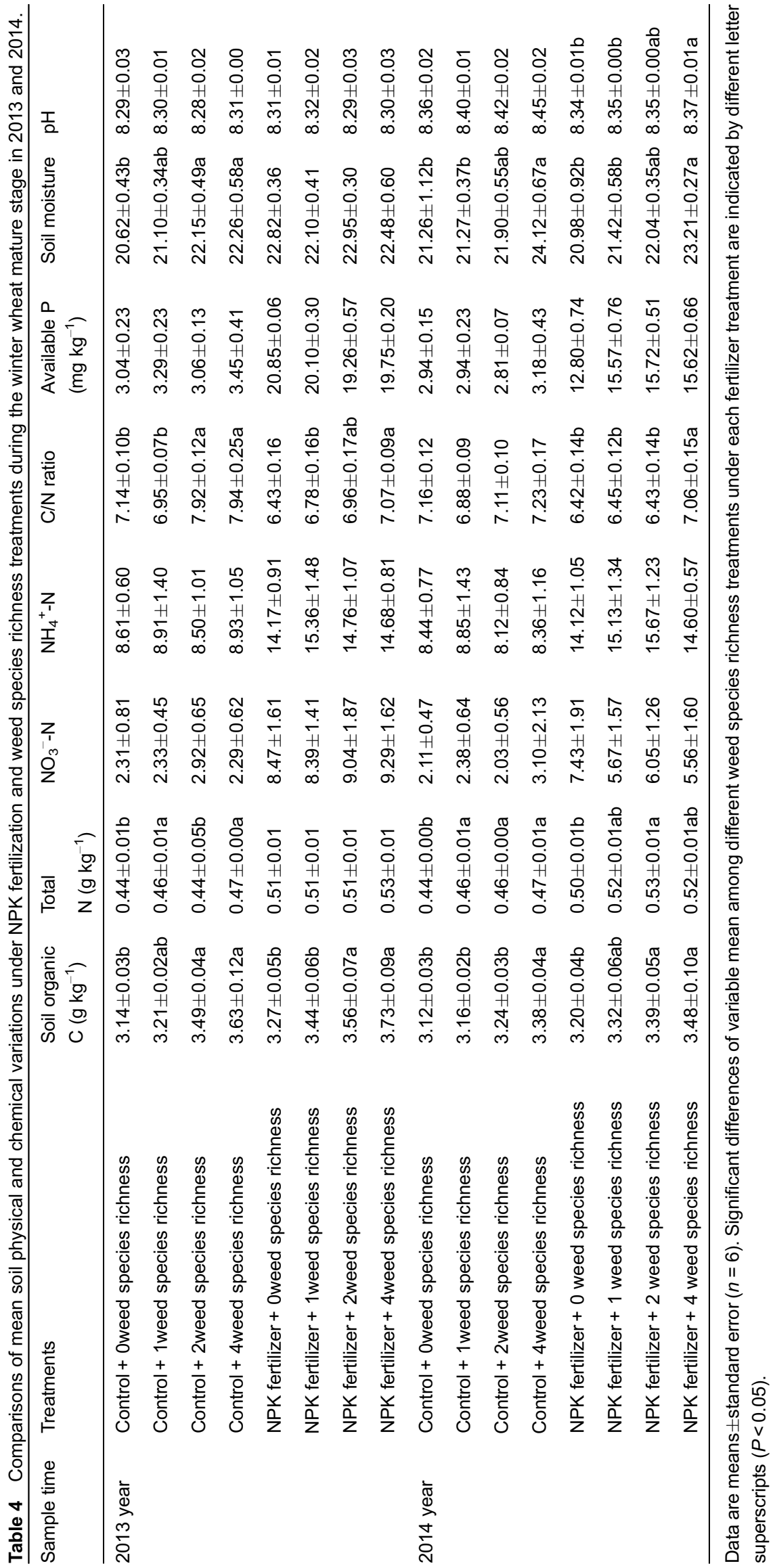




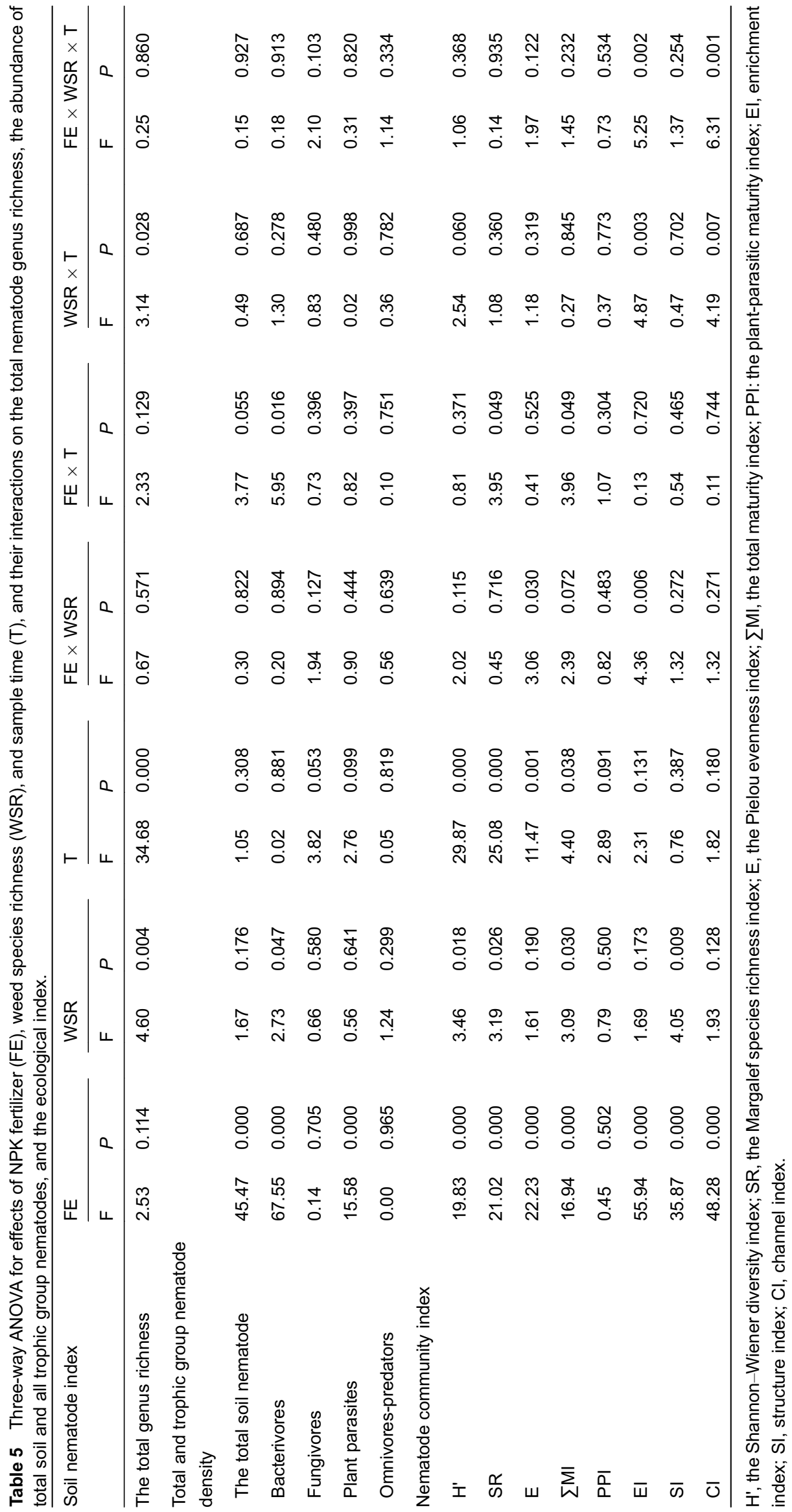




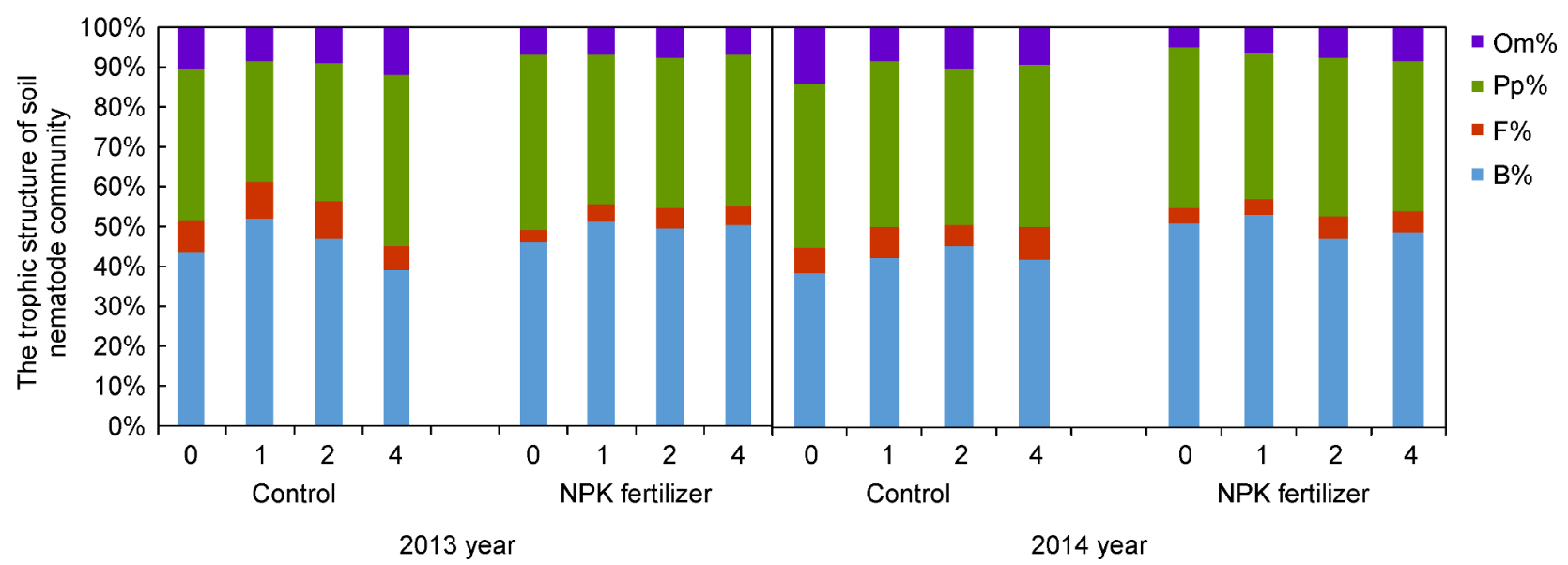

Fig. 3 The trophic structure of the soil nematode community under NPK fertilizer and weed species richness treatments in 2013, and 2014 year. $0,1,2$, and 4 represents $0,1,2$, and 4 weed species richness, respectively. Replicates are 6.
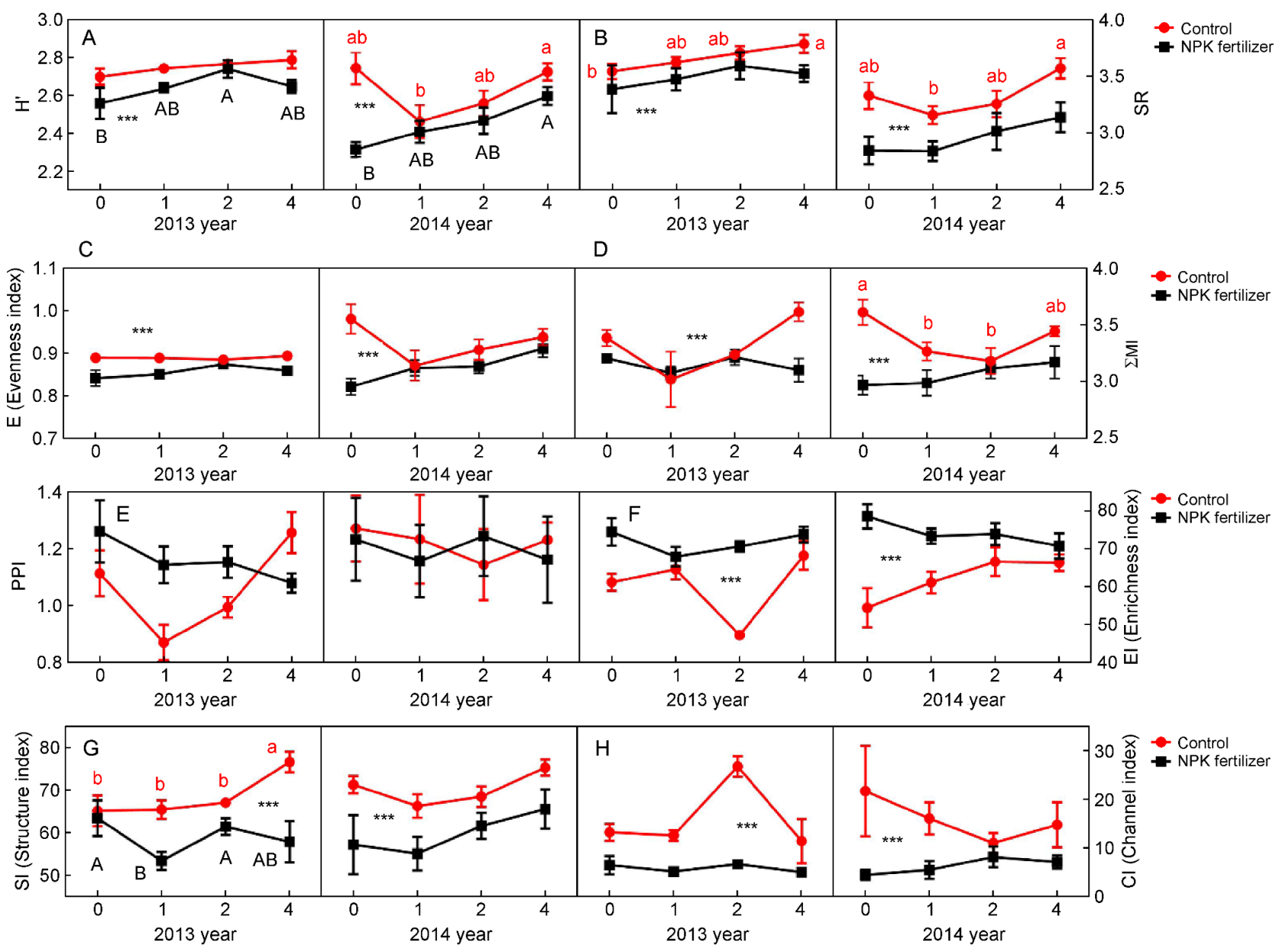

Fig. 4 The Shannon-Wiener diversity index $\left(\mathrm{H}^{\prime}\right)$ (Fig. 4A), the Margalef species richness index (SR) (Fig. 4B), the Pielou evenness index (E) (Fig. 4C), the total maturity index ( $\sum \mathrm{MI}$ ) (Fig. 4D), plant-parasitic index (PPI) (Fig. 4E), enrichment index (EI) (Fig. 4F), structure index (SI) (Fig. 4G) and channel index (Cl) (Fig. 4H) under NPK fertilizer and weed species richness treatments in 2013 and 2014. All valued are means $\pm \mathrm{SE}(n=6) .0,1,2$, and 4 represents $0,1,2$, and 4 weed species richness, respectively. *** indicates the significant difference between the control and NPK fertilizer treatments. Lowercase and capital letters represent the significant differences under the different weed species richness in control and NPK fertilizer treatments, respectively. 


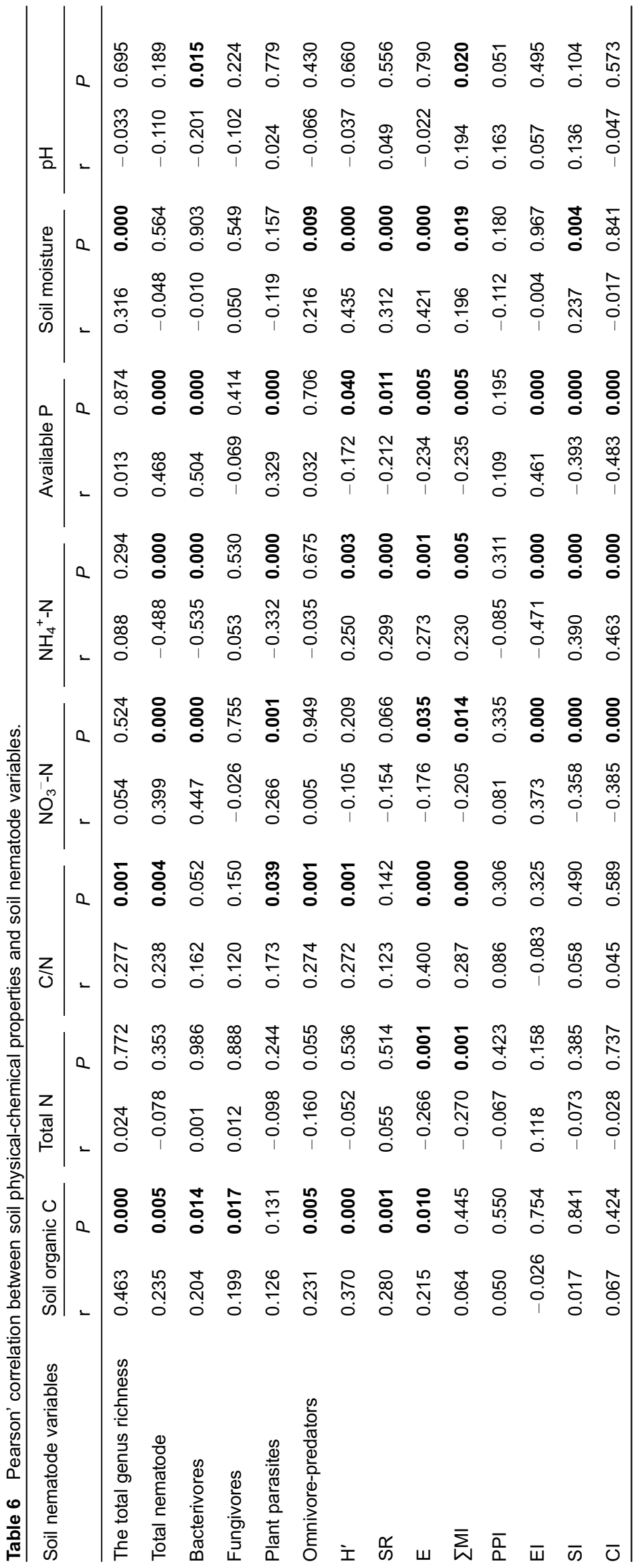




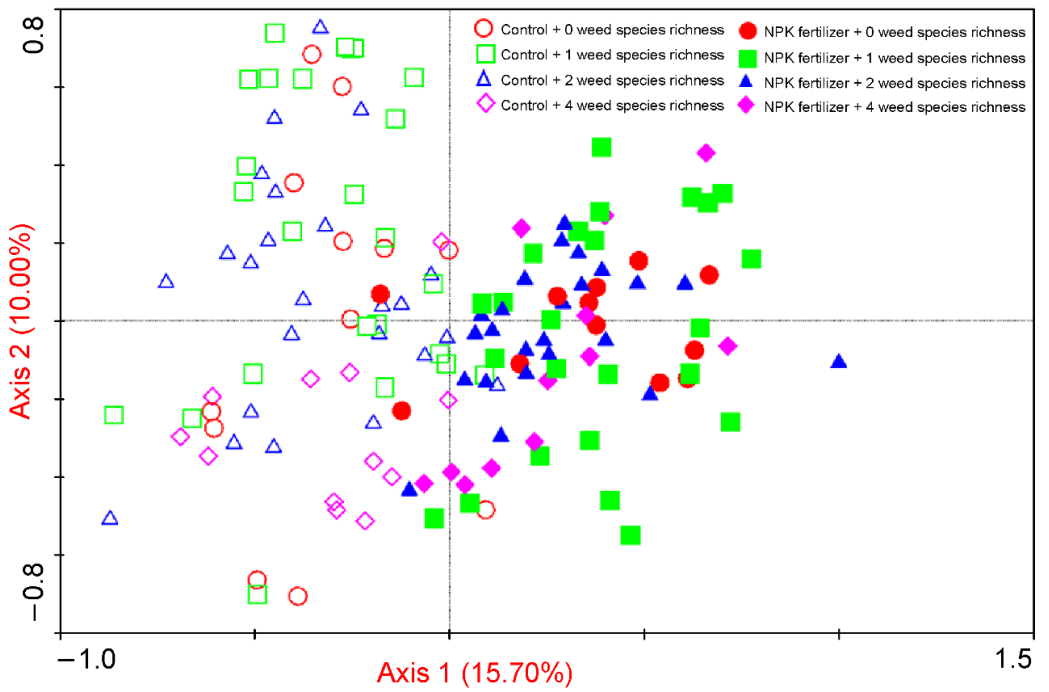

Fig. 5 PCA of the effect of NPK fertilizer and weed species richness on soil nematode community composition. Axis 1 , and 2 represents $\mathrm{PC} 1$, and $\mathrm{PC} 2$, respectively. $15.70 \%$, and $10.00 \%$ represents the contribution rate of $\mathrm{PC} 1$, and $\mathrm{PC} 2$ to the overall variance, respectively.

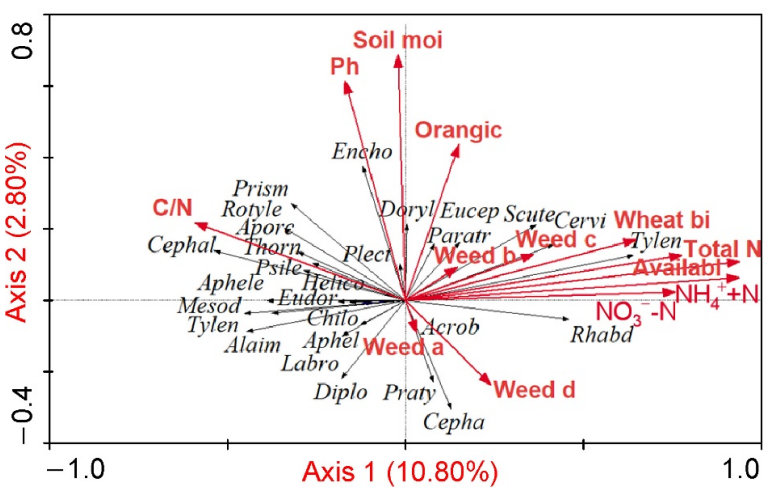

Fig. 6 Biplot of Redundancy analysis (RDA) of the relationship between soil physical-chemical properties, wheat biomass, weed biomass and soil nematode community composition. Axis 1 , and 2 represents RDA1, and RDA2, respectively. $10.80 \%$, and $2.80 \%$ represents the explain contribution of environmental factors to soil nematode community variation, respectively. $\mathrm{C} / \mathrm{N}$ : the ratio of carbon to nitrogen; Soil moi: soil moisture; Organic: organic carbon; Weed a, Weed b, Weed c, and Weed d represent the biomass of Medicago sativa, Cichorium intybus, Avena fatua, and Descurainia Sophia, respectively. Total N: total nitrogen; Availabl: available phosphorus; $\mathrm{NO}_{3}{ }^{-} \mathrm{N}$ : nitrate nitrogen; $\mathrm{NH}_{4}{ }^{+}-$ $\mathrm{N}$ : ammonium nitrogen; $\mathrm{Ph}$ : $\mathrm{pH}$; Wheat bi: wheat biomass.

total nematode abuncance might be that soil in the long term NPK fertilizer addition had more soil organic $\mathrm{C}$, total $\mathrm{N}, \mathrm{NO}_{3}{ }^{-}$ $\mathrm{N}$, and available $\mathrm{P}$. The abundance of bacterivores was higher in the NPK fertilizer than in control treatments, which indicated that the enhancing contents of organic $C$ and available $P$ in the soil treated with NPK fertilizer promoted microbial activity and biomass, providing more food for bacterivores (Sarathchandra et al., 2001). NPK fertilizer significantly increased the abundance of plant parasites, which was consistent with previous study findings, which demonstrated that chemical fertilizer treatment could increase plant-parasitic nematodes relative to control (Wang et al., 2006). The reason may be ascribed to the higher plant biomass, growth, and excretion of root (Vestergård, 2004; Majdi and Nylund, 1996) in the NPK fertilizer treatments than in control treatments (Table 2). These results indicated that fertilizer increased the abundance of total nematodes, bacterivores, and plant-parasites, which was contrary to our first hypothesis.

The ecological indices of $\mathrm{H}^{\prime}$ are linked to the diversity of soil nematodes. $\mathrm{H}^{\prime}$ was higher in the control than in the NPK fertilizer treatments in this study, which implies a trend of more extraordinary soil nematode biodiversity and a relatively stable environment in the control treatments. Our result indicated that the control treatments have higher nematode diversities in agreement with a previous study (Lenz and Eisenbeis, 2000). The lower SR in the NPK fertilizer treatments indicates a less complicated community structure, and the lower $\mathrm{E}$ showed the uneven distribution of soil nematode. In the present study, NPK fertilizer significantly increased the contents of $\mathrm{NO}_{3}{ }^{-} \mathrm{N}, \mathrm{NH}_{4}{ }^{+}-\mathrm{N}$, and available $\mathrm{P}$, which potentially had negative impacts on the total genus richness and $\mathrm{E}$ index of soil nematodes. Therefore, NPK fertilizer decreased the soil nematode community's diversity, which was supportive of our first hypothesis.

Nematode abundance disagreed, but diversity agreed, with our first hypothesis. The reason may be that Rhibditis, Tylenchorhynchus had higher relative abundance in NPK fertilizer (Supplement Table 1, and Supplement Table 2) than in the control treatments, which resulted in decreasing nematode diversity.

The lower $\sum \mathrm{Ml}$ showed highly disturbed soil ecosystems in the fertilizer treatments. El reflects the availability of resources to the soil food web and primary decomposers' response to the resources (Ferris et al., 2001). In our study, El values were higher in the case of NPK fertilizer treatment than for the control treatments under all weed species richness 
treatments. The higher SI values in the control plot indicated a complex and stable food web. The lower SI values in the NPK fertilizer treatments implied that the soil food web had fewer trophic links compared with the control treatments. The relative abundance of omnivore-predators in the control treatments was partially responsible for the difference in SI values. The nematode channel index $\mathrm{Cl}$ was developed to evaluate decomposition pathways (Ferris et al., 2001). The $\mathrm{Cl}$ values were lower in the NPK fertilizer than those in the control treatments, reflecting the lower abundance of fungivores in the fertilizer treatments, and the bacteria-dominated decomposition pathway is characteristic of the fertilizer treatments.

\subsection{Effect of weed species richness on the soil nematode} community

Except for bacterivore abundance, weed species richness had no impact on soil nematode abundance, which was not in agreement with the supposition that weed species richness may increase the abundance of soil nematode. The reason may be the single weed species had different effects on nematode abundance. For example, the abundance of bacterivores, plant parasites, and omnivore-predators was the highest under the single weed Descurainia sophia, Avena fatua, and Medicago sativa treatments, respectively. However, the lowest abundance of bacterivores, fungivores, plant parasites, and omnivore-predators was found under the single weed Avena fatua, Cichorium intybus, Descurainia sophia, and Cichorium intybus, treatments, respectively. Effects of 2 or 4 weed species richness on soil nematode abundance may be mutually counteracted, and the reason may be that root exudation of different weed species has negative or positive effect on the abundance of soil nematode. Our study indicated weed species richness significantly increased the total nematode genera number in accordance with a previous study (De Deyn et al., 2004; Dietrich et al., 2021). In the present study, the positive correlations between the total nematode genera number and soil organic carbon, the $\mathrm{C} / \mathrm{N}$ ratio, soil moisture confirmed that weed species richness could positively affect the total nematode genera number. One reason may be that high weed species diversity released more organic material from living roots by sloughing-off border cells, secretion of mucilage, root exudation, and senescence of root epidermis (Nguyen, 2003) and promoted the accumulation of soil organic matter (Fornara and Tilman, 2008; Eisenhauer et al., 2013). High weed species richness increased the $\mathrm{C} / \mathrm{N}$ ratio and soil moisture (Table 3 ), which may be one reason. Another reason may be that enrichment of resource availability by increasing the weed species richness could alleviate the intensity of interspecific competition and increase the total nematode genera number (Sohlenius et al., 2011).

In terms of nematode ecological indices, weed species richness increased $\mathrm{H}^{\prime}$, and because the $\mathrm{E}$ index was similar, it was mainly the total nematode genera number that caused this difference in $\mathrm{H}^{\prime}$. Another reason may be the increasing weed species richness which led to the increase of plant functional groups. Because in our study the highest weed species richness contained the most plant functional groups including Legume (Medicago sativa), Composite (Cichorium intybus), Forb (Avena fatua), and Cruciferae (Descurainia sophia). Furthermore, the increased plant functional groups resulted in a more diversified environment, which supported more diversity of soil nematode genera. The increase of soil nematode genera led to an increase in $\mathrm{H}^{\prime}$. Previous study demonstrated that increasing plant species richness significantly increased diversity of collembolan (Sabais et al., 2011). However, another study demonstrated that a higher diversity of plant species did not increase the diversity of nematodes (Viketoft et al., 2009). The increase of SR was also ascribed to the increase of the total nematode genera number. These results partly demonstrated weed species richness increased the diversity index of soil nematode community.

Weed species richness significantly increased $\sum \mathrm{MI}$, and SI, which was attributed to the complementarity in resource quality of the component plant species (Deyn et al., 2004) and the increasing quantity and diversity of resource in the soil food web but did not influence $\mathrm{El}$ and $\mathrm{Cl}$. The high $\sum \mathrm{MI}$ and $\mathrm{SI}$ values indicated weed species richness enhanced soil food web structure (Ferris et al., 2001).

\subsection{The effect of the sample time}

The increase of total genus richness was ascribed to high total weed biomasses in the year 2013. Total weed biomasses were increased by $44.56 \%$ in 2013 , compared with in 2014 . The increase of weed biomasses may provide the food resource of soil nematode and support a more abundant nematode population through "bottom-up" control (Keith et al., 2009). More abundant nematode population promotes the genus richness of soil nematode.

The higher $\mathrm{E}$ and high total genus richness resulted in the increase of H' in 2013, relative to that in 2014. The increase of total genus richness resulted in the increase of SR. The lower $\Sigma \mathrm{Ml}$ in 2013 was due to the enrichment effect of soil nematode. The enrichment-opportunists Rhabditis, Diplogastrellus, and Caenorhabditis relative abundance and total nematode abundance in 2014 was higher than that in 2013, which resulted in the higher $\sum \mathrm{Ml}$.

4.4 The interactive effect of fertilizer and weed species richness on the soil nematode community

The interactive effects of fertilizer and weed species richness on soil nematodes were found only in $E$ and $E I$, which supported our second hypothesis. The NPK fertilizer inhibited the growth of weeds and decreased weed species richness (Tang et al., 2014), which resulted in the interaction effect on the $E$ index of the soil nematode community. The presumable reason may be the NPK fertilizer treatment had the lowest light transmittance, and weeds are sensitive to light. Therefore the lower light transmittance on the ground may be one of the 
main reasons weed species richness was reduced (Tang et al., 2014). Fertilizer significantly increased soil nutrients' content, which improved winter wheat and weed biomass growth (Table 2). Weed Medicago sativa, and weed Cichorium intybus produces perennial roots, maintaining high soil organic carbon (Dupont et al., 2014) and a rich environment. Therefore, the interaction of fertilizer and weed species richness affected $\mathrm{EI}$.

Application of fertilizer decreased the total genera number, $\mathrm{H}^{\prime}, \mathrm{SR}, \sum \mathrm{MI}$, and SI. In contrast, weed species richness increased these indices, which indicated that weed species richness counteracted the negative effect of fertilizer on the soil nematode community. Fertilizer and weed species richness affected soil nematode community mainly by changing soil physical-chemical properties (Fig. 6). PCA analysis indicated that fertilizer's effect on soil nematode was more significant than the effect of weed species richness on soil nematode community, which demonstrated our third hypothesis. The results suggest that in the long term species-rich plant communities experience higher levels of nutrient cycling and $\mathrm{N}$ availability than species-poor communities (Reich et al., 2012). We suggest that weed conservation seems a promising step in fertilized farmland, which improves soil nematode diversity and enhances the soil nematode community.

\section{Conclusion}

In summary, our results demonstrated that long-term fertilizer addition in agroecosystem increased soil nematode abundance, whereas it decreased the ecological indices of soil nematode community and degraded the soil food web. In contrast, except for bacterivore density, weed species richness had no effects on the abundance of soil nematode but increased the soil nematode community's ecological indices and enhanced the structure of the soil nematode community. Weed species richness weakened the negative effect of the fertilizer treatments on the soil nematode community. Our findings also suggest that maintaining appropriate weed species richness in the fertilizer treatments may improve ecosystems' stability and provide a better understanding of weed integrated management in farmland ecosystems.

\section{Author contributions}

Conceptualization, X.N., and Y.G.; investigation, X.N., X.F., S.C., and F.S.; writing — original draft preparation, X.N.; writing — review and editing, X.N., F.S, and Y. G. All authors have read and agreed to the published version of the manuscript.

\section{Acknowledgments}

This study was supported by the National Natural Science Foundation of China (31070394) and the Natural Science Project of Henan Province (162300410009), and the National
University Innovation and Entrepreneurship Training Program (202110475087).

We gratefully thank Junpeng Wang for editing and reviewing the manuscript, Cancan Zhao, for the help of data analysis.

\section{Conflicts of interest}

The authors declare no conflict of interest.

\section{Electronic supplementary material}

Supplementary material is available in the online version of this article at https://doi.org/10.1007/s42832-021-0123-1 and is accessible for authorized users.

\section{References}

Anderson, L.J., 2011. Aboveground-belowground linkages: Biotic interactions, ecosystem processes, and global change. Eos (Washington, D.C.) 92, 222-222.

Anwar, S., Zia, A., Javed, N., Shakeel, Q., 2009. Weeds as reservoir of nematodes. Journal of Nematology 27, 145-153.

Bao, S., 2000. Soil analysis in agricultural chemistry. China Agriculture Press: Beijing.

Barker, K.R., 1985. Nematode Extraction and Bioassays, In: Barker, K.R., Carter, C.C., Sasser, J.N.,eds. An advanced treatise on Meloidogyne. North Carolina State University Graphics, Raleigh, NC, USA, pp. 19-35.

Blackshaw, R.E., Molnar, L.J., Janzen, H.H., 2004. Nitrogen fertilizer timing and application method affect weed growth and competition with spring wheat. Weed Science 52, 614-622.

Bongers, T., 1999. The Maturity Index, the evolution of nematode life history traits, adaptive radiation and cp-scaling. Plant and Soil 212, 13-22.

Chen, X.P., Cui, Z.L., Vitousek, P.M., Cassman, K.G., Matson, P.A., Bai, J.S., Meng, Q.F., Hou, P., Yue, S.C., RÖmheld, V., Zhang, F. S., 2011. Integrated soil-crop system management for food security. Proceedings of the National Academy of Sciences of the United States of America 108, 6399-6404.

De Deyn, G.B., Raaijmakers, C.E., Van Ruijven, J., Berendse, F., Van Der Putten, W.H., 2004. Plant species identity and diversity effects on different trophic levels of nematodes in the soil food web. Oikos 106, 576-586.

Deyn, G.B., Raaijmakers, C., Ruijven, J., Berendse, F., Putten, W., 2004. Plant species identity and diversity on different trophic levels of nematodes in the soil food web. Oikos 106, 576-586.

Dietrich, P., Cesarz, S., Liu, T., Roscher, C., Eisenhauer, N., 2021. Effects of plant species diversity on nematode community composition and diversity in a long-term biodiversity experiment. Oecologia 197, 297-311.

Dupont, S., Beniston, J., Glover, J., Hodson, A., Culman, S., Lal, R., Ferris, H., 2014. Root traits and soil properties in harvested perennial grassland, annual wheat, and never-tilled annual wheat. Plant and Soil 381, 405-420.

Eisenhauer, N., Dobies, T., Cesarz, S., Hobbie, S., Meyer, R., Worm, 
K., Reich, P., 2013. Plant diversity effects on soil food webs are stronger than those of elevated $\mathrm{CO}_{2}$ and $\mathrm{N}$ deposition in a longterm grassland experiment. Proceedings of the National Academy of Sciences of the United States of America 110, 6889-6994.

Eisenhauer, N., Reich, P., Scheu, S., 2012. Increasing plant diversity effects on productivity with time due to delayed soil biota effects on plants. Basic and Applied Ecology 13, 571-578.

Feng, W., Pan, G., Qiang, S., Li, R., Wei, J., 2008. Influence of longterm different fertilization on soil weed seed bank diversity of a paddy soil under rice/rape rotation. Frontiers of Biology in China 3, 320-327.

Ferris, H., Bongers, T., de Goede, R.G.M., 2001. A framework for soil food web diagnostics: extension of the nematode faunal analysis concept. Applied Soil Ecology 18, 13-29.

Ferris, H., Matute, M.M., 2003. Structural and functional succession in the nematode fauna of a soil food web. Applied Soil Ecology 23, 93-110.

Forge, T.A., Bittman, S., Kowalenko, C.G., 2005. Responses of grassland soil nematodes and protozoa to multi-year and singleyear applications of dairy manure slurry and fertilizer. Soil Biology \& Biochemistry 37, 1751-1762.

Fornara, D.A.T., Tilman, D., 2008. Plant functional composition influences rates of soil carbon and nitrogen accumulation. Journal of Ecology 2, 314-322.

Gibbons, D., Bohan, D., Rothery, P., Stuart, R.C., Haughton, A., Scott, R., Wilson, J.D., Perry, J.N., Clark, S.J., Dawson, R.J.G., Firbank, L.G., 2006. Weed seed resources for birds in fields with contrasting conventional and genetically modified herbicide-tolerant crops. Proceedings. Biological Sciences 273, 1921-1928.

Hu, C., Qi, Y., 2010. Effect of compost and chemical fertilizer on soil nematode community in a Chinese maize field. European Journal of Soil Biology 46, 230-236.

Hu, C., Xia, X.G., Han, X.M., Chen, Y.F., Qiao, Y., Liu, D.H., Li, S.L., 2018. Soil nematode abundances were increased by an incremental nutrient input in a paddy-upland rotation system. Helminthologia 55, 322-333.

Jiang, M., Liu, T., Huang, N., Shen, X., Shen, M., Dai, Q., 2018. Effect of long-term fertilisation on the weed community of a winter wheat field. Scientific Reports 8, 4017.

Keith, A.M., Brooker, R.W., Osler, G.H.R., Chapman, S.J., Burslem, D. F.R.P., van der Wal, R., 2009. Strong impacts of belowground tree inputs on soil nematode trophic composition. Soil Biology \& Biochemistry 41, 1060-1065.

Lenz, R., Eisenbeis, G., 2000. Short-term effects of different tillage in a sustainable farming system on nematode community structure. Biology and Fertility of Soils 31, 237-244.

Lepš, J.Š.P., 2003. Multivariate analysis of ecological data using CANOCO. Cambridge University Press, New York.

Loreau, M., Naeem, S., Inchausti, P., Bengtsson, J., Grime, J.P. Hector, A., Hooper, D.U., Huston, M.A., Raffaelli, D., Schmid, B., Tilman, D., Wardle, D.A., 2001. Biodiversity and ecosystem functioning: current knowledge and future challenges. Science 294, 804-808.

Lu, Q., Liu, T., Wang, N., Dou, Z., Kunguang, W., Zuo, Y., 2020. A review of soil nematodes as biological indicators for the assessment of soil health. Frontiers of Agricultural Science and
Engineering 7, 275-281.

Lu, Z., Dong, D., Yang, B., Li, L., Yu, Y., Ouyang, F., Ge, F., Verma, V., Men, X.Y., 2016. Effects of crop species richness on the community of soil nematodes in an experimental agro-ecosystem. European Journal of Soil Biology 73, 26-33.

Majdi, H., Nylund, J.E., 1996. Does liquid fertilization affect fine root dynamics and lifespan of mycorrhizal short roots? Plant and Soil 185, 305-309.

Marshall, E.J.P., Brown, V.K., Boatman, N.D., Lutman, P.J.W., Squire, G.R., Ward, L.K., 2003. The role of weeds in supporting biological diversity within crop fields. Weed Research 43, 77-89.

Neher, D.A., 2001. Role of nematodes in soil health and their use as indicators. Journal of Nematology 33, 161-168.

Nguyen, C., 2003. Rhizodeposition of organic C by plants: mechanisms and controls. Agronomie 23, 375-396.

Okada, H., Harada, H., 2007. Effects of tillage and fertilizer on nematode communities in a Japanese soybean field. Applied Soil Ecology 35, 582-598.

Pan, F., McLaughlin, N.B., Yu, Q., Xue, A.G., Xu, Y., Han, X., Li, C., Zhao, D., 2010. Responses of soil nematode community structure to different long-term fertilizer strategies in the soybean phase of a soybean-wheat-corn rotation. European Journal of Soil Biology 46, 105-111.

Reich, P., Tilman, D., Isbell, F., Mueller, K., Hobbie, S., Flynn, D., Eisenhauer, E., 2012. Impacts of biodiversity loss escalate through time as redundancy fades. Science 336, 589-592.

Ross, D., Van Acker, R.C., 2009. Effect of nitrogen fertilizer and landscape position on wild oat (Avena fatua) interference in spring wheat. Weed Science 53, 869-876.

Sabais, A.C.W., Scheu, S., Eisenhauer, N., 2011. Plant species richness drives the density and diversity of Collembola in temperate grassland. Acta Oecologica 37, 195-202.

Sarathchandra, S.U., Ghani, A., Yeates, G.W., Burch, G., Cox, N.R., 2001. Effect of nitrogen and phosphate fertilisers on microbial and nematode diversity in pasture soils. Soil Biology \& Biochemistry 33, 953-964.

Scherber, C., Eisenhauer, N., Weisser, W., Schmid, B., Voigt, W., Fischer, M., Schulze, E.D., Roscher, C., Weigelt, A., Allan, E., Beßler, H., Bonkowski, M., Buchmann, N., Buscot, F., Clement, L. W., Ebeling, A., Engels, C., Halle, S., Kertscher, I., Klein, A.M., Koller, R., König, S., Kowalski, E., Kummer, V., Kuu, A., Lange, M., Lauterbach, D., Middelhoff, C., Migunova, V.D., Milcu, A., Müller, R., Partsch, S., Petermann, J.S., Renker, C., Rottstock, T., Sabais, A., Scheu, S., Schumacher, J., Temperton, V.M., Tscharntke, T., 2010. Bottom-up effects of plant diversity on multitrophic interactions in a biodiversity experiment. Nature 468, 553-556.

Schmitz, J., Schäfer, K., Brühl, C.A., 2014. Agrochemicals in field margins-Field evaluation of plant reproduction effects. Agriculture, Ecosystems \& Environment 189, 82-91.

Sieriebriennikov, B., Ferris, H., de Goede, R.G.M., 2014. NINJA: An automated calculation system for nematode-based biological monitoring. European Journal of Soil Biology 61, 90-93.

Sohlenius, B., Boström, S., Viketoft, M., 2011. Effects of plant species and plant diversity on soil nematodes-A field experiment on grassland run for seven years. Nematology 13, 115-131.

Sun, F., Tariq, A., Chen, H., He, Q., Guan, Y., Pan, K., Chen, S., Li, J., 
Zhao, C., Wang, H., Gu, Y., 2016. Effect of nitrogen and phosphorus application on agricultural soil food webs. Archives of Agronomy and Soil Science 63, 1176-1186.

Tang, L., Wan, K., Cheng, Ch., Li, R., Wang, D., Pan, J., Tao, Y., Xie, J., Chen, F., 2014. Effect of fertilization patterns on the assemblage of weed communities in an upland winter wheat field. Journal of Plant Ecology 7, 39-50.

Thomas, S., Schroeder, J., Murray, L., 2009. The role of weeds in nematode management. Weed Science 53, 923-928.

Todd, T.C., 1996. Effects of management practices on nematode community structure in tallgrass prairie. Applied Soil Ecology 3 , 235-246.

Vestergård, M., 2004. Nematode assemblages in the rhizosphere of spring barley (Hordeum vulgare L.) depended on fertilisation and plant growth phase. Pedobiologia 48, 257-265.

Viketoft, M., Bengtsson, J., Sohlenius, B., Berg, M., Petchey, O., Palmborg, C., Huss-Danell, K., 2009. Long-term effects of plant diversity and composition on soil nematode communities in model grasslands. Ecology 90, 90-99.

Wan, K., Tao, Y., Li, R., Pan, J., Tang, L., Chen, F., 2012. Influences of long-term different types of fertilization on weed community biodiversity in rice paddy fields. Weed Biology and Management 12, 12-21.

Wang, K.H., McSorley, R., Marshall, A., Gallaher, R., 2006. Influence of organic Crotalaria juncea hay and ammonium nitrate fertilizers on soil nematode communities. Applied Soil Ecology 31, 186-198.

Wardle, D.A., Bardgett, R.D., Klironomos, J.N., Setälä, H., van der Putten, W.H., Wall, D.H., 2004. Ecological linkages between aboveground and belowground biota. Science 304, 1629-1633.

Yeates, G.W., 2003. Nematodes as soil indicators: functional and biodiversity aspects. Biology and Fertility of Soils 37, 199-210.
Yeates, G.W., Bongers, T., De Goede, R.G., Freckman, D.W., Georgieva, S.S., 1993. Feeding habits in soil nematode families and genera-an outline for soil ecologists. Journal of Nematology 25, 315-331.

Zhang, W., Liu, M.Q., He, Y.Q., Fan, J.B., Chen, Y., 2014. Responses of soil nematode communities to long-term application of inorganic fertilizers in upland red soil. Journal of Applied Ecology 25, 23612368.

Zhang, X., Jiang, Y., Liang, L., Zhao, X., Li, Q., 2009. Response of soil nematode communities to long-term application of inorganic fertilizers in the black soil of Northeast China. Frontiers of Biology in China 4, 111-116.

Zhang, Z., Zhang, X., Mahamood, M., Zhang, S., Huang, S., Liang, W., 2016. Effect of long-term combined application of organic and inorganic fertilizers on soil nematode communities within aggregates. Scientific Reports 6, 31118.

Zhao, J., Neher, D.A., 2013. Soil nematode genera that predict specific types of disturbance. Applied Soil Ecology 64, 135-141.

Zhao, J., Shao, Y., Wang, X., Neher, D.A., Xu, G., Li, Z., Fu, S., 2013. Sentinel soil invertebrate taxa as bioindicators for forest management practices. Ecological Indicators 24, 236-239.

Zhao, R.F., Chen, X.P., Zhang, F.S., Zhang, H., Schroder, J., Römheld, V., 2006. Fertilization and nitrogen balance in a wheat-maize rotation system in north China. Agronomy Journal 98, 938-945.

Zheng, F., Dong, Z., Chen, Q., Bi, Q., O'Connor, P., Zhu, Y.G., 2020. The driving factors of nematode gut microbiota under long-term fertilization. FEMS Microbiology Ecology 96, 1-11.

Zhu, X., Zhu, B., 2015. Diversity and abundance of soil fauna as influenced by long-term fertilization in cropland of purple soil, China. Soil \& Tillage Research 146, 39-46. 